\title{
Semiotic Characteristics of the 9th Grade Math Textbook
}

\author{
Mohammad Ahmad Alkhateeb
}

Hashemite University, Zarqa, Jordan, mkm7879@yahoo.com

\begin{abstract}
This study employed the social semiotic method to analyze the 9 th grade textbook in Jordan. Through analyzes three texts-related major aspects: intellectual function, interpersonal function, and textual function. The results showed that math is abstract, and assertive, and that math is located in a self-independent realm, with its own mathematical beings and with the existence of an official and far relationship between the book and the student. The math textbook tends to show the students as if they are merely ordered implementers.
\end{abstract}

Keywords: intellectual function, interpersonal function, textual function, math textbook analysis, systematic functional linguistics (SFL).

\section{Introduction}

In the past decade or so, the students' math performance was a source of worry for the teachers (Chiesi \& Caterina, 2010; Pape \& Wang, 2003; Schoen, Cebulla, Finn \& Fi, 2003; Torbeyns, Schneider, Xin \& Siegler, 2015). One of the hypothesized reasons for the poor performance is the textbooks that are used as the main source for math teaching in schools. This is particularly true as the math textbooks are widely accepted as a commonly used source in math teaching. The study of (Hiebert et al., 2003) found that $91-100 \%$ of the sample the teachers in many countries largely depend on the math textbook.

Several studies have analyzed elements of the Jordanian curriculum: content, goals, method of teaching, activities, evaluation, and among these studies, such as the study of (Alyat \& Duwairy, 2015) which aimed at analyzing the geometry content of mathematics textbooks in the light of (NCTM, 2000). The study of (Rababah \& Miqdadi, 2017) that investigated the compliance of Jordan's reformed mathematics textbooks for first-graders 
to the National Council of Teachers of Mathematics' (NCTM, 2000) standards. Study of (Qaisi, 2014), which identified the realization of mathematical connectivity standard in $8^{\text {th }}$ Grade Math Book in Jordan, and its Actualization in classroom practice. And, the study of (Ramamneh, Abu Lum, Karameen, Hiasat, 2015), which aimed to analyze the content of the mathematics books of the first to fourth grades of the foundational schooling stage in Jordan, in the light of the standards of (NCTM, 2000), which are specific to mathematical processes.

However, none of these studies looked into how the other language and semiotic properties of the texts affect math teaching, or into the focus on math nature and nature of the anticipated math activity of the students. Therefore, recent research on math teaching-learning drew attention to the linguistic methodology to analyze the math textbooks. The most important frameworks depend on the language aspect to analyze the social semiotic math curricula (Morgan, 2006). The social semiotics depends on Halliday's functional rules (Halliday, 1985).

The work of Halliday (1973) and Morgan (2004) supports the research provided in this paper, which aims to apply a scale to analyze the language of the math textbooks. Halliday's research provides the base for many areas of language analysis and focuses on the functional aspects of the language (most often referred to as the Systematic Functional Linguistics "SFL"), which emerged from his works (Halliday, 1973). Its purpose is to interpret the language within its functional context, i.e. Scans the language in use and the objective of such usage (Morgan \& Sfard, 2011; Morgan \& Tang, 2012; Moschkovich, 2010; Tang, Morgan \& Sfard, 2012).

Among the research that has been conducted internationally in mathematics education, Morgan's (2006) use of SFL to visualize processes in school mathematical assessments is the most well-known. However, others such as (Meaney, Trinick \& Fairhall, 2012) have also used it to find different genres in written mathematics texts, produced by the students. Morgan (2006) claims that these functional rules, when applied in math teaching, presume that every moment of the mathematical communication not only tackles the math concept and relations but also the interpersonal meanings, the situations, and beliefs. This assumption helps us avoid dealing with cognition in isolation from the other human activity aspects.

Morgan developed a linguistic framework for analyzing mathematical texts based on systemic functional linguistics for Halliday (1985). This science is based on the idea that any text can fulfill three basic functions: the intellectual function, the interpersonal function, and the textual function, Morgan has based this framework on a fundamental idea, which is the idea of options, as the language provides us with multiple and varied options. It provides us with the opportunity to use the singular in exchange for plural, and to use the past tense, present or future, to use the pronouns of the speaker, the absent or the addressee, and to use words that express suspicion or express certainty. Each of these users has a different connotation from others, which means that when we choose one of 
the options without the other, even if without our intent and awareness, the interpretation that you can build from reading or hearing our words may be so affected (Morgan, 1996).

Semiotics analyzes the text according to three main functions: intellectual function, interpersonal function, and textual function. The intellectual function in the mathematical text is related to the math nature, the doer in the math text, how far the human is present in the text, and the role of the human in the mathematical action (Halliday \& Matthiessen, 2004).

Halliday $(1978,1985)$ sees that the intellectual function searches in the math nature and image. Is math absolute and valid in every place and time, or is it a human work not separated from reality? Does the language in which the math texts are written push us to build an idea about math that it is a self-independent realm that has no relation to the human work in it and that the task of the human in it is limited only in an attempt to discover its mathematical objects, and identify its secrets that are embedded in it? Or else, does it push us to feel that math is a dynamic, continuously changing work that we are able to form the way we want, and that what is currently available of math knowledge and thoughts could be replaced by other math thoughts? (Austin \& Howson, 1979; Ernest, 2004; Dossey, 1992).

Morgan (1996) employs the transitive system. To find out the math nature and image through the idea of choices. Transitively appears in two sorts: types of processes and types of participants in these processes. Halliday (1985) characterized six types of these processes: material, mental, relational, behavioral, emotional and verbal. When we analyze the intellectual function, we look at the types of the six processes. For instance, the mental processes are feeling processes of three types: sensory perception (sees, hears, etc.), emotional perception (likes, hates, etc.), and mental perception (thinks, knows, understands, etc.). There are participants in mental processes: the person who feels and the phenomenon. We can identify the mental processes through the actions that need thinking and intellectual effort (e.g.: A right-angle triangle, where two of its sides are equal, and the square of the third side is $32 \mathrm{~cm}^{2}$, calculate the length of the two other sides).

Meanwhile, the material processes belong to the real world, they are physical processes. There are two participants in the material processes: the actor (doer) and the objective. To identify the material processes in the math texts, we have to find out the functions that need to do practical activities, such as I draw, solve, divide and extend (e.g. I use the calculator and find out cosine of angle 64). Meanwhile, the behavioral processes occur between the material and mental processes, and the behavioral process is an intransitive one (with only one participant), which represents an action with which the behavioral and mental processes are combined.

The verbal processes are acts of speech that include three participants: the speaker, the receiver and the speech. The existential processes represent something existing or something occurring. The relational processes could be identified through the existence of relations between the mathematical objects (e.g.: link straight angle measurement 
with the measurement of two right angles). The equals sign assists us in distinguishing the relational process from the other processes, as it always signifies symmetry relations between two mathematical objects (Morgan, 1996). There are three types of relational processes. Similarity or symmetry processes (e.g.: the square is a rectangle where there are two equal adjacent sides); situational processes (e.g.: the polygon diagonal is a piece "line" connecting two nonadjacent sides in the polygon); and, possession processes (e.g.: the quadratic shapes group includes parallelograms group) (Morgan, 1996).

It is important when looking for participants in the mathematical process to determine their role in these processes, such as, do they appear through the active voice or disappear through the passive voice? It is also important to use nominalization, i.e. converting the math verb into a noun. Types of the participants in the math process could be seen by the active voice (e.g.: I prove that the area DEF ABC). Here the verb "prove" is in the active voice tense, which means that the learner participates in the learning process, and this participation shows that mathematics is a human activity. On the other hand, the example (the $\mathrm{ABC}$, were divided into two halves) shows that the verb "divided" is in the passive voice tense, which means the absence of the human presence. It implies as if the angle was found divided without an active verb, which may leave the impression that mathematics is a self-independent realm.

However, the option to use the active voice does not mean that the image that is adopted for mathematics is necessarily a human process. To be so, the doer to which the verb refers must be the learner, while when the doers are the mathematical signs, symbols, and terms, they express the absolute image of mathematics. For example, two triangles correspond when each has three equal symmetric sides. Here the verb corresponds was assigned to the doer (two triangles), as if the two triangles are who do the congruence process alone. Furthermore, the image of mathematics can be identified through the nominalization, through the example (total of the triangle angles is 180).

Choosing one of the processes without the other would make us build a different interpretation of the image of mathematics. We may not actually mean to use the mental process, the Material, process, or the relational process in our writing, but when we read what is written, we will build a different world if the process used is physical, mental, or relational.

The interpersonal function looks into the role of both the learner and author in the mathematical text, as well as their mutual relations. This function represents the social and personal relations between them. exploration of these relationships is through the use of first person pronouns (I, we), as their use indicates the participation of both the author and the learner in the math process, the interest of the student in it, and that this use gives the learner a type of responsibility in building the math ideas (e.g.: Using a protractor, I check that the angles are equal) and, (We substitute the value of $\mathrm{x}$ and the value of $y$ in the equation). In addition, the use of pronouns (you) indicates a close relationship 
between the author and the learner, which makes the learner involved in the study of mathematics, but the author draws the learner's attention with a degree of authority.

Also, the disappearance of pronouns indicates an official relationship between the author and the learner, so there does not seem to be a relationship between them, (e.g. If two lines intersect, then they intersect in exactly one point). and the use of the imperative tense (e.g.: note, explain, compare, find out), Whereas the use of this formula, gives the learner a role in participating in building mathematical ideas, and in this context (Morgan, 1996) differentiates between two types of imperatives, the general (e.g.: We conclude from this), which considers the learner to be a thinker. , and special that the learner considers the scribbler in the mathematical process (e.g.: Draw a circle with the center $\mathrm{m}$ ).

The separation of the intellectual and interpersonal functions does not mean that they do not overlap with each other. For example, when we look at the mathematical text and find that the subject is not a human being; that at the level of the intellectual function it expresses the image of mathematics as absolute and has nothing to do with human existence, while at the level of the interpersonal function and the same indicator there is a disappearance The actor means that the relationship between the author and the learner is formal.

The textual function is about the role the language itself plays in the text, i.e. the way the word used in the text, for instance, in terms of description, order or explanation. It is also related to the text consistency and salience and the characteristics that make the learner distinguish the type of text from among a pool of texts. The textual function is associated with the text progress: does the text progress from the given to the result, from the known to the new, or does it progress as logical and causal text? (Schleppegrell, 2007).

Several studies have analyzed the text of the mathematical textbook using semiotic social analysis. In this context, the Study of Shwaikh and Morgan (2013) analyzed the math textbook using the social semiotic analysis, in which they analyzed the eighth grade math textbook in Palestine in the triangles congruence topic. They also compared this text with a similar math text in the British curriculum and found that there are some differences between the two texts. For example, the focus was on the conversion processes in the British text while this focus was not clearly seen in the Palestinian text.

O'Keffee (2013) conducted a study based on the semiotic analysis framework, which aimed at building a framework to analyze the math texts in the Irish curriculum books. The study relied on the semiotic analysis framework as one of three theoretical frameworks, to build a suitable theoretical framework to analyze the text of the math textbook. The study of O'Keffee \& O'Donoghue (2011) aimed at analyzing the texts of the math textbooks in the Irish curriculum, and exploring their role in encouraging math students' understanding and motivation. The results showed that the language elements that most affect the students' motivation and focus of math studying are the use of pronouns, passive voice sentences, informal sentences, symbols, signs and tenses of the verb. 
Setati (2002) explored the relationship between teaching mathematics and language. Morgan (1996) analyzed the math texts to identify the intellectual, reciprocal and textual functions, which the students may build through these texts. Other researchers employed Morgan's framework (1996) to analyze the math texts, such as (Herbel-Eisenmann \& Wagne, 2007; Morgan, 2011; Morgan, 2006; Morgan, 2004; Shwaikh, 2012).

Haggarty and Pepin (2002) analyzed the mathematics textbooks used in England, France and Germany to identify the image of mathematics in them, and found that the prevailing image of mathematics is certain and not questionable, nor is it affected by the cultural context in which it occurs and that the authors of mathematics books appeared as if they possess the knowledge, whereas (AlShuwaikh, 2012) in his analysis of how to present the concept of probabilities in Palestinian mathematics textbooks, he found that the concept of probabilities shows human activity in the fourth and fifth grades while starting from the sixth grade, the passive voice verb begins to appear, while in the tenth and twelfth grades He finds that mathematical symbols and terms have come to dominate the concept of probability, and in an analysis (Eisenmann, 2007) of mathematics textbooks, found that there is a fair use of nominalization.

We also find in Shilling's analysis (2010) of three books used in pre-service math courses for primary school teachers, the nominalization was repeated in both the first and second books 14 times and in the third book 50 times. Nominalization was not only used in mathematics textbooks, in Morgan's analysis of student writing work, but it was also found that students used it in their solutions to varying degrees (Morgan, 1996, 2006), although the nature of one of the two tasks requires experimentation and physical work in order to achieve generalization. This comes as a result of students being affected by the nature of textbooks, in which they find the appropriate model for mathematical writing.

The current research comes as a complementary work of the previous research, which used the semiotic analysis to analyze the content of the $9^{\text {th }}$ grade math textbook. The study aims to identify the properties of the math textbook in terms of the learnerss role as a human, role of the author, and verb tenses and pronouns in the text, which indicate the author-learner interpersonal relation, as well as the progress of the mathematical text.

Although semiotics imposed itself in international studies since the seventies of the $20^{\text {th }}$ century and formed various currents that varied according to the subjects of the study, we note the absence of the application of the semiotics approach in the analysis of Arab textbooks in general, and the analysis of mathematics books in particular, especially in the middle east region, including Jordan. We also note that the absence of this curriculum has led to the loss of important analytical tools that could have exposed many social and humanitarian phenomena in the content of textbooks.

Very few studies that analyzed the Arabic math textbooks used this trend. This analysis can draw the attention of the officials of the ministry of education for important aspects in the math textbooks such as: What role is the learner's? What acts are expected of him/her? What is the relation between the author and learner? How to improve these 
relations? How does the math textbook progress according to the learner? And, what are the suggestions to improve this progress? The results of the analysis will be of vast importance to the developers of the textbooks and math teachers. The researcher even believes that this will be of a more generalized international relevance.

\section{Study Questions:}

- How is the intellectual function manifested in the $9^{\text {th }}$ grade math textbook?

- How are the author-learner interpersonal relations manifested in the $9^{\text {th }}$ grade math Textbook?

- How does the text of the $9^{\text {th }}$ grade math textbook progress?

\section{Methodology}

Data of the study: Within the study framework, the researcher analyzed the $9^{\text {th }}$ grade math textbook (part two), which includes four units: the relative bases unit (4 lessons); the coordinate geometry unit (4 lessons); the trigonometric ratios unit (6 lesson); and the geometry unit (4 lessons). This book forms the main source of both the teachers and students in Jordan, as the ministry of education prepares and distributes the textbooks over the schools. The way the math textbooks prepared in Jordan is similar to their peers in the world, as they are based on (NCTM, 2000) standards.

Analysis method: The researcher analyzed the $9^{\text {th }}$ grade math textbook according to the social semiotic manner, in search for particular values of the three functions (intellectual, interpersonal and textual). Thereafter, in search for categories that include these values and their partial values. Then the researcher applied the quantitative analysis to calculate the frequencies of each of the values and the partial categories. It could be said that the analysis method is basically a content deductive analysis, taking into account the categories and the social semiotic dependent values. In search of the values and categories, the researcher considered the categories and values, which (Morgan, 1996; O’Keffee \& O’Donoghue, 2011; Shwaikh \& Morgan, 2013) dealt with.

More specifically, to analyze the intellectual function in the math textbook, the researcher used the categories that exist in the study of O'Keffee \& O'Donoghue (2011). Namely: the nature of the processes carried out by the learner (physical, mental, relational, verbal, behavioral, existential); the nature of the participants (learner, mathematical object, unnamed, nominalization); and the nature of the mathematical element, which could be (signs, symbols, figures, language, patterns, life situations). On the other hand, the math element could express initial description, official definition, intuition, rule or congruence. Moreover, the math element could be basic or derivative, such as when the math relation is intuitive, it will be basic, while the theories resulting from the intuition are derived from it. 
For the analysis of the interpersonal function, the researcher explored the pronouns that are used in the text. For instance, the pronoun "we" indicated the attempt by the author to incorporate the learner into the math audience. The types of the verbs were also explored, particularly the imperative, as the imperative tense verb implies a far relation between the textbook and the learner. Here, the researcher relied on the works of (Halliday, 1985; Morgan, 2006).

To analyze the textual function, the researcher explored the text progress and depended on the work of (Shwaikh \& Morgan, 2013; O'Keffee \& O’Donghue, 2011), more specifically on the work of Shwaikh and Morgan (2013). Then he explored whether the text proceeds (given/prior-new), (new-applied) or (applied-evaluative). Furthermore, depending on the work of O'Keffee and O'Donghue (2011), the researcher explored whether the text advances as a concurrent thinking and linkage toward reasoning (as a result, despite), or as a logical concurrent thinking and linkage toward logical reasoning (therefore, base of), or as an obligatory thinking and imperative in order (next, then).

Reliability: Two specialists analyzed the math textbook and the agreement factor was calculated between them based on Cohen (1960) (Cohen's kappa). The agreement factor was 0.89, which is an excellent agreement rate, according to Cicchetti (1994).

\section{Results}

The First Question: How is the intellectual function manifested in the $9^{\text {th }}$ grade math Textbook?

Generally, the math textbook embodied mathematics as if it is a realm with its own objects and beings, and that the math objects are able to carry out the math processes along without the human's help. This is quite clear from the large use of the active voice (the doer is a math object), the passive voice, and the shift to the nominalization at the rate of $(28.84 \%)$ of the total verbs of the book $(n=728)$. The book abundantly used the corporeal functions at the cost of the intellectual. The corporeal verbs rate accounted for (25.86\%) of the total learner-related verbs in the textbook ( $\mathrm{n}=518)$, such as the imperatives (draw, create, use, write, fill, cut). As for the rate of the mental verbs, such as (analyze, realize, explain, conclude, discuss, prove) it was (15.83\%). Meanwhile, the rate of the relational verb, such as (represents) amounted (30.69\%). Other verb rates were as follows: the verbal verb (11.96\%), such as (we say, we call); and the behavioral verb (12.16\%), such as (find. calculate, arrange, complete). Finally, the existential verb rate was (3.74\%), such as the verb (there is). Table (1) illustrates the first aspect of the intellectual function, which is the type of processes and the participants that are present in the mathematical text. 
Table 1

Process Recurrence as Per Their Types and the Participants in the $9^{\text {th }}$ Grade Math Textbook

\begin{tabular}{|c|c|c|c|c|c|c|c|c|c|c|c|}
\hline \multirow[b]{2}{*}{$\begin{array}{l}\text { Math Text } \\
\text { Units }\end{array}$} & \multicolumn{7}{|c|}{ Learner-related Verbs } & \multicolumn{4}{|c|}{ Others } \\
\hline & 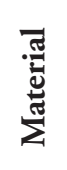 & & & 竞 & ص⿺辶ّ & 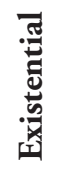 & ڤేّ & 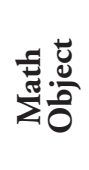 & 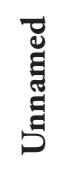 & 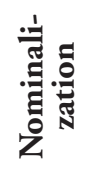 & قّٓ \\
\hline Relative Bases & 36 & 28 & 43 & 25 & 25 & 7 & 167 & 12 & 10 & 22 & 44 \\
\hline $\begin{array}{l}\text { Coordinate } \\
\text { Geometry }\end{array}$ & 31 & 24 & 40 & 15 & 20 & 5 & 135 & 13 & 11 & 28 & 52 \\
\hline $\begin{array}{l}\text { Trigonometry } \\
\text { Ratios }\end{array}$ & 33 & 18 & 41 & 12 & 10 & 4 & 118 & 19 & 17 & 35 & 71 \\
\hline Geometry & 34 & 12 & 35 & 10 & 8 & 2 & 101 & 11 & 9 & 23 & 43 \\
\hline Total & 134 & 82 & 159 & 62 & 63 & 18 & 518 & 55 & 47 & 108 & 210 \\
\hline
\end{tabular}

In the second aspect of the intellectual function, which is the essence of the math element, as stated in the math textbook, attention was drawn to the math concepts and their interrelations. Two partial aspects were explored: the essence of the element (initial description, official definition, intuition, rule), and whether the element is basic or derived.

The results showed that the focus of the textbook was less on the math element than on the applications and math exercises. Therefore, there were too many rules that help in solving the math problems, as the basic rule rate was $(49.98 \%)$ of the total basic elements $(n=61)$. On the other hand, the derived rule rate amounted (31.21\%) of the total derived elements $(\mathrm{n}=66)$, the derived initial description amounted $(13.63 \%)$ of the total derived elements, and the basic official definition rate was (16.66\%) of the total basic elements. As for the derived official definition, it accounted for (34.84\%) of the total derived elements. Finally, the basic intuitive rate and derived intuitive rate were (16.39\%) and (13.63\%), respectively.

Table 2

Recurrence of the Math Element Type in the Math Textbook

\begin{tabular}{|c|c|c|c|c|c|c|c|c|c|c|}
\hline \multirow[t]{3}{*}{ Math Text } & \multicolumn{10}{|c|}{ Math Elements } \\
\hline & \multicolumn{2}{|c|}{$\begin{array}{c}\text { Initial } \\
\text { Description }\end{array}$} & \multicolumn{2}{|c|}{$\begin{array}{c}\text { Official } \\
\text { Definition }\end{array}$} & \multicolumn{2}{|c|}{ Intuition } & \multicolumn{2}{|c|}{ Rule } & \multicolumn{2}{|c|}{ Total } \\
\hline & صू & 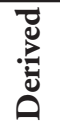 & 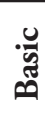 & 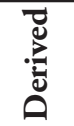 & 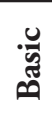 & 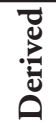 & 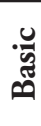 & 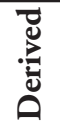 & 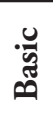 & 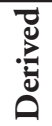 \\
\hline Relative Bases & 13 & 3 & 2 & 6 & 0 & 0 & 7 & 6 & 22 & 15 \\
\hline Coordinate Geometry & 0 & 6 & 3 & 3 & 2 & 0 & 5 & 1 & 10 & 10 \\
\hline Trigonometric Ratios & 1 & 0 & 3 & 4 & 6 & 2 & 8 & 3 & 18 & 9 \\
\hline Geometry & 1 & 0 & 3 & 10 & 2 & 7 & 5 & 4 & 11 & 32 \\
\hline Total & 15 & 9 & 11 & 23 & 10 & 9 & 25 & 14 & 61 & 66 \\
\hline
\end{tabular}


In the matter of the third aspect of the intellectual function, the representations that exist in the math textbook, the results showed a specialized image of mathematics to a wide extent. The textbook is "crowded" with math symbols of multiple purposes. The use is not only limited to read these symbols but also to probe deep in every symbol to perceive the math facts it has. The representation rates of the math elements in the math textbook were as follows: representation by symbols (42.73\%), by pictures and figures (13.78\%), by language (37.77\%), by models (1.10\%), and by life situations ( $4.59 \%)$. Table (3) illustrates a third aspect of the intellectual function, i.e. the representations in the ninth grade math textbook.

Table3

Mathematical Representations Frequencies in the Math Textbook

\begin{tabular}{|c|c|c|c|c|c|c|}
\hline \multirow[b]{2}{*}{ Textual Text } & \multicolumn{6}{|c|}{ Math Elements Representations } \\
\hline & $\begin{array}{l}\frac{n}{0} \\
\text { है } \\
\text { है }\end{array}$ & 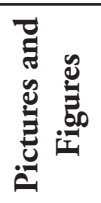 & 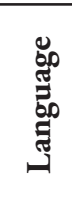 & $\frac{\frac{0}{0}}{\frac{0}{0}}$ & 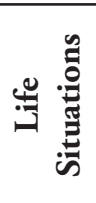 & Total \\
\hline Relative Bases & 112 & 5 & 105 & 4 & 6 & 232 \\
\hline Coordinate Geometry & 114 & 17 & 98 & 1 & 7 & 237 \\
\hline Trigonometric Ratios & 132 & 65 & 121 & 4 & 31 & 353 \\
\hline Geometry & 107 & 63 & 87 & 3 & 6 & 266 \\
\hline Total & 465 & 150 & 411 & 12 & 50 & 1088 \\
\hline
\end{tabular}

The Second Question: How are the author-learner interpersonal relations manifested in the $9^{\text {th }}$ grade math Textbook?

The results showed an official relation between the textbook and the learner, which is quite apparent through the absence of the pronouns. There must be a relation between them, as the rate of the pronoun absence amounted (26.83\%). The results also showed that the learner is not given a basic role, and the second person pronouns (you) appeared instead of the first person pronouns (I, we), which underline the role of the learner. The learner's role appeared as a mere order implementer (scribbler), while the basic power is given to the author (textbook), which indicates that the pedagogical author-learner relation was low. In this concern, the rate of the learner as order implementer was (93.04\%), but was only (6.95\%) as a thinker. As for the rates of pronouns in the math textbook, they were as follows: (5.09\%) pronoun "we" (such as we suppose, note, conclude); (67.82\%) pronoun "you" (such as: find, calculate, explain, define); and (0.00\%) pronoun "I". Generally, it is clear that the basic power is the author's (textbook's), due to the dominance of the second person pronouns (you) in the mathematical text, as compared with the first person 
pronoun (1). The pronouns used in the textbook tended to order implementation rather than thinking. Table (4) shows the author-learner interpersonal function indications.

Table 4

Recurrence of the Author-Learner Interpersonal Relation Indications

\begin{tabular}{|c|c|c|c|c|c|c|c|c|c|c|c|}
\hline \multirow[b]{2}{*}{ Mathematical Text } & \multicolumn{5}{|c|}{$\begin{array}{l}\text { Student as Order } \\
\text { Implementer }\end{array}$} & \multicolumn{5}{|c|}{ Student as a Thinker } & \multirow[b]{2}{*}{ Total } \\
\hline & 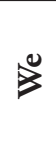 & ב्र & - & 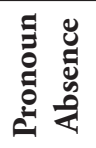 & 气ีّ & 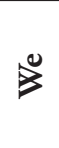 & $\ddot{\theta}$ & - & 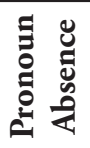 & 气ีّ & \\
\hline Relative Bases & 5 & 0 & 120 & 44 & 169 & 4 & 0 & 6 & 6 & 16 & 185 \\
\hline Coordinate Geometry & 6 & 0 & 128 & 50 & 184 & 3 & 0 & 7 & 2 & 12 & 196 \\
\hline Trigonometric Ratios & 17 & 0 & 135 & 68 & 220 & 5 & 0 & 11 & 3 & 21 & 241 \\
\hline Geometry & 1 & 0 & 133 & 42 & 176 & 0 & 0 & 6 & 1 & 7 & 183 \\
\hline Total & 29 & 0 & 516 & 204 & 749 & 12 & 0 & 30 & 12 & 56 & 805 \\
\hline
\end{tabular}

The Third Question: How does the text of the $9^{\text {th }}$ grade math Textbook progress?

As for the text progress, two aspects were explored. The first is the text progress by a process (given/prior-new), (new-applied), (applied-evaluative). The second is the text progress (reasoning, logical linkage, obligation by order). The results showed that the rate of the text progress (given/prior knowledge-new knowledge) accounted for (53.31\%), while the text progress (new knowledge-applied knowledge) amounted (23.17\%). On the other hand, the text progress rate (applied knowledge- evaluative knowledge) accounted for $(73.50 \%)$, where the evaluation was in the form of a drill, exercise and problem. Table (5) indicates the text progress frequency as a process.

Table 5

Text Progress Frequency as a Process

\begin{tabular}{lcccc}
\hline \multirow{2}{*}{ Math Text } & \multicolumn{4}{c}{ Text Progress } \\
\cline { 2 - 5 } & Previous-New & New-Applied & Applied-Evaluative & Total \\
\hline Relative Bases & 3 & 14 & 35 & 52 \\
\hline Coordinate Geometry & 4 & 14 & 69 & 87 \\
\hline Trigonometric Ratios & 3 & 30 & 74 & 107 \\
\hline Geometry & 0 & 12 & 44 & 56 \\
\hline Total & 10 & 70 & 222 & 302 \\
\hline
\end{tabular}

As for the second aspect, which is the text progress (reasoning, logical linking, obligation by order), the results showed that the reasoning link rate amounted (25\%), the logical linking (10.71\%), and the obligation by order (64.28\%), as illustrated in Table (6). 
Table 6

Text Progress Frequency as Reasoning

\begin{tabular}{lcccc}
\hline \multicolumn{1}{c}{ Mathematical Text } & $\begin{array}{c}\text { Reasoning } \\
\text { Link }\end{array}$ & $\begin{array}{c}\text { Logical } \\
\text { Linking }\end{array}$ & $\begin{array}{c}\text { Obligation } \\
\text { by Order }\end{array}$ & Total \\
\hline Relative Bases & 5 & 1 & 9 & 15 \\
\hline Coordinate Geometry & 5 & 3 & 5 & 13 \\
\hline Trigonometric Ratios & 4 & 2 & 7 & 13 \\
\hline Geometry & 0 & 0 & 15 & 15 \\
\hline Total & 14 & 6 & 36 & 56 \\
\hline
\end{tabular}

\section{Discussion}

In this study, the researcher analyzed the ninth grade math textbook according to the three functions to analyze the text (the intellectual function, interpersonal function, and textual function) (Halliday, 1985). Two analysis frameworks were combined, which were developed by (Morgan, 1996; O’Keeffe \& O’Donoghue, 2011; Shwaikh \& Morgan, 2013). Generally, it could be said that the study results indicated that the textbook showed math as if it is abstract, formal, symbolic and assertive, located in an independent selfrealm with its own mathematical beings, due to the dominance of the math objects that carry out the mathematical processes. We found this mathematical nature throughout all the units we analyzed, but it differs from one unit to another.

The results showed that The prevalent characteristic is a tendency to keep mathematics away from the students, as the words that are used in the math textbook, suggest that there is a distance not close between students and mathematics, This distance was clear through the too much use of the active voice -an actor is a mathematical object. (e.g.: If two lines intersecting, then exactly one plane contains the lines). Thus, the two lines are the doer, which carried out the process of intersect, without a reference to any human who drew this lines, which makes us see that mathematics is an independent world in which mathematical beings are the one that performs all mathematical verbs on their own. In addition, there was the use of the passive voice, especially in generalizations. (e.g.: the group of points on one flat is called flat points group, but those that do not fall on one flat are called non-flat points group). The book also employed nominalization. (e.g.: every two supplementary angles together make 180).

The results showed that mathematics is a pool of relations in which the math objects carry out the mathematical processes, which form the relations upon which math is built. For example, we find that the total of the triangle angles $=180$ degrees. In this sentence, the verb "add" was changed into a noun "total", a process called "nominalization" (Morgan, 1996). For examples, the following two sentences hold the same math fact, but they are different in wording: 
1- If we add the angles of any triangle together, we shall get 180 .

2- Total of the triangle angles is 180.

Both sentences tell about the angles of the triangle, but they differ in terms of the math image they display because of the different wording. The first shows that the human is taking part in building the math fact through carrying out the angles addition operation, which implies that mathematics is a human activity. Meanwhile, when the verb "add" was changed into the noun "total", it led to that there is no need for a doer to do the addition process, as if as the angles are the "party" that was assigned the addition process. This implies that math is an independent realm; all its facts and rules are "ready made" without our interference.

However, the use of the relational functions to a wide extent is not only confined to the Jordanian math textbooks, but it was also found at Morgan \& Tang (2012). They analyzed the papers of the examinations taken in England during (1995-2011) and showed that the percentage of using the relational processes increased between these two years. and this was demonstrated by Sharafa (2015), who analyzed the Palestinian math textbooks.

Concurrently with alienating the ninth graders from the math, the intellectual function is used in terms of the processes of both the author and the learner, which shortens the distance between the students and the math. This was underlined by the results of the intellectual function study, which provided that the relational process and the material process were the most often used from among the human processes, followed by the mental process and the behavioral process, with the existential process, was the least used. Based on the study of Morgan (1996), one can tell that the apparent mathematics of the distribution of these processes this way is a preexisting object, which could be followed by the learner. At the same time, they are also composed of relations that could be built by the learner due to plenty of relational processes. The existence of material and behavioral processes implies a complicated view of mathematics. Most specifically, it is a preexisting object the student is required to reach, or identify one way or the other (O’Donnell, Zappavigna \& Whitelaw, 2008).

No wonder, then, if we find this image in the Jordanian math book, especially because the prevalent math stereotype image is formal and symbolic (Dossey, 1992; Ernest, 2004; Morgan, 1996; Shilling, 2009). This result is also found in several studies, such as (Haggarty \& Pepin, 2002; Morgan, 2004; Shwaikh, 2012; Shwaikh \& Morgan, 2013). For example, Davis \& Hersh (1981) wrote about the writings of the ideal mathematician and provided that they should be "void" of any indication to that the writer is a human, or who reads them is a human, and that the words used should not raise any type of doubts in their accuracy.

The results of the current study also showed that the rules or identities rates were higher than the other mathematical components, whether the original or the derivatives. The least rate of the types of the mathematical elements was of the intuitions, which is an expected result. The math textbooks are almost void of intuitions, except for some intuitions about the geometry chapters. A small rate was for the initial description or the 
official definition of the mathematical element, which means that the author's interest was not in the math element as much as it was for the interest in math applications and exercises. Therefore, there is plenty of rules and identities that help to carry out math applications and assist in solving mathematical exercises and problems.

Furthermore, the results indicated that the symbolic representation is the most in use as compared with the other representations. In this concern, the lessons of the units are overcrowded with the math symbols, which were used for multiple purposes. This made mathematics appear as abstract, formal, symbolic and assertive, falls in its own independent self-realm, with its own mathematical objects and symbols.

As the results of the analysis showed that the ninth grade mathematics book was crowded with mathematical symbols that were used for multiple purposes and that some pages contain only mathematical symbols, such as, mathematical symbols used to express intersection, orthogonality, and parallelism, for example, $A \cap B=\{C\}$. This sentence includes five mathematical concepts: straight, plane, intersection, point and group, in addition to the relationship of equality between mathematical symbols. The matter does not only depend on reading mathematical symbols, but it dives into each of these symbols to find out the mathematical facts that are involved, which is more difficult for students, some of which is the result of lack of familiarity with the correct reading skills, Resulting in, weakness in reading mathematical symbols properly.

In this context, Morgan presented three sentences to a group of primary and secondary mathematics teachers and mathematics pedagogical researchers (Morgan, 2001):

- The rectangle has equal diameters

- If you measure the diameters of the rectangle, you will find them equal

- Measuring the lengths of the diameters of any rectangle are always equal

Then he asked them which of the sentences is more mathematical? Most of them answered that the first formula is the most mathematical, though. As we note, the three formulas speak of the same information about diameters in a rectangle, but in different ways. The choice of the first sentence is due to the fact that it emphasizes the absolute nature of mathematics, while we find that the second sentence has an appearance of human activity that attempts to validate and verify mathematical facts, and the third sentence uses temporal expressions such as: always, which makes the second and third sentences contradict the nature of absolute mathematics that you see that mathematical facts are true at all times and do not need to be verified and validated.

The absolute image of mathematics also controls the beliefs of many school and university students, as it was found (Crawford, Gordon, Nicholas \& Prosser, 1994) that $73 \%$ of the three hundred college students at an Australian university see mathematics as abstract and formal and that they are only numbers or symbols or laws used to solve problems, and such an outcome is found in (Petocz, Wood, Smith, Mather, Harding, Engelbrecht, et al., 2006). The absolute view that these students hold can be attributed to a number of factors, including the image of mathematics in the mathematics textbooks they teach, 
and the image of mathematics carried by their teachers, which appears through the teaching ways they use to teach mathematical ideas (Dossey, 1992; Sovič \& Hus, 2016).

As for the author-learner interpersonal relations in the ninth grade math textbook, the results showed a formal relationship between the author and the learner. This is quite clear through the "absence of the pronouns", which implies that there is no relation between them. On the other hand, the learner is not given a basic role in the textbook, as the second person pronouns (you) appeared instead of the first person pronouns (I, we) that underline the role of the learner, and the basic authority was for the author (textbook). The formal relationship would build barriers between students and mathematics, who see it as a private and strange world, and they afraid to enter it, as a difficult and complicated subject that is full of specialized symbols that confuse them. This is what (Herbel-Eisenmann, 2007) observed as there was no use of the speaker's conscience during the unit she analyzed.

The analysis results further showed that the math textbook tends to give a negative image of the math learner; that he/she is merely implementer of the orders (scribbler), that the orders are predetermined, and that the learner has only to "obey" them, without a space given to think freely and critically. He/she is not given the different choices to follow the way he/she deems fit to reach the math facts. All the lessons have one planned and drawn way by the textbook designer, and the students have nothing to do but go the way this planning goes to reach the math facts. The nonappearance of the learner as a thinker indicates that the negative behavioral view about the students is still there. Accordingly, the learner is a mere vessel where the information are put and stored until they are retrieved at the examination time, and that he/she has no role in building his/her knowledge by his/her own (O'Keeffe \& Donoghue, 2015; Tang, Morgan, \& Sfard, 2012).

The use of the speech pronoun "we" in mathematical texts show the learner's involvement in mathematical verb (Morgan, 1996, 2006). It also indicates that learner's have a role in building mathematical ideas, which correspond to the modern theories (constructivism and social constructivism) that view students as the ones who build and develop their understanding and knowledge of themselves and not through receiving knowledge in a ready and orderly way (Presmeg, Radford, Roth \& Kadunz, 2016; Troelstra \& Van Dalen, 2014).

As for the progress of the mathematical text in the ninth grade math textbook, the analysis results showed that most of the text progress was by (applied-evaluative) process, and the least by (prior knowledge- new knowledge) process. This result implies that the book should pay more attention to the (prior knowledge-new knowledge) process due to its importance for the student's learning. Through this process, we can link between what the student knows and what we want him/her to know. This linkage is called for by many mathematical educational literatures, such as: (Grouws \& Cebulla, 2000; NCTM, 2000; O’Keeffe, \& Donoghue, 2015; Shin, 2019). On the other hand, the "obligation by order" linkage was the most used, while the logical reasoning was the least, which means that reasoning was not the main 
focus of the textbook. In fact, reasoning is required throughout all the school stages as an important feature of mathematics teaching-learning (NCTM, 2000).

\section{Conclusions}

This study employed the social semiotics to analyze the Jordanian ninth grade math textbooks. The results showed that mathematics is abstract, formal and assertive, and falls within an independent self-realm with its own mathematical objects due to the dominance of the mathematical objects that carry out the mathematical processes, which the student should reach or identify one way or the other. On the other hand, the rate of the rules or identities was the highest of all the other math elements, with the symbolic representation being the most used as compared with other representations. It is at this point that the study calls for work to develop the math textbooks in a manner that shows the other image of mathematics as a human activity, where the students are engaged in the learning process more effectively. Thereby, they will be given space for thinking to make them more than mere order implementers and followers of predetermined steps, and to encourage them to use more different representations in the math textbooks. It is at this point that the study calls for work to develop the math textbooks in a way that shows mathematics as a human activity, where the students are actively involved in the learning process so that they are given the field to think more than just implementers and following pre-defined steps, and to encourage them use more different representations in the math textbooks.

As for the author-learner interpersonal relations, the pronoun "you" was widely used, which confirms a formal and "distant" relationship between the book and the student. Accordingly, the study recommends that the student should be at the core of the mathematical event, and, at the same time, the relation between the student and the book should be close. As long as the analysis result showed that the math textbook tends to show the students as implementers, work could be oriented to qualify the teachers to "make" students able to think freely. This could be achieved through teachers' encouragement to engage them in written activities and tasks that focus on how far they comprehend the math content, as well as focus on the thinking mechanism they carried out to illustrate how they reached the solution.

In the matter of the text progress as a process, the results showed no interest in the progress from the student's prior knowledge to the new knowledge. Therefore, the study calls for more attention to this aspect due to its importance and effect on the student's learning. As for the text progress as reasoning, the results showed that "obligation by order" was the most used, and the logical reasoning was less used. This implies that the book did not place sufficient attention to reasoning, and this calls us to underline the need for more attention by the ministry of education to this feature throughout all the educational stages, starting with the early educational stage. 


\section{References}

Alyat, I., \& Duwairy, A. (2015). Content Analysis of the Geometry Content Included in Mathematics Textbooks for the Intermediate Basic Stage in Jordan in light of The International Standards (NCTM, 2000), Dirasat Journal, 42(3), 747-765.

Austin, J. \& Howson, A. (1979). Language and Mathematical Education. Educational Studies in Mathematics, 10, 161-197.

Chiesi, F., \& Caterina, P. (2010). Cognitive and Non-cognitive Factors Related to Students' Statistics Achievement. Statistics Education Research Journal, 9(1), 6-26.

Cicchetti, D. (1994). Guidelines, Criteria, and Rules of Thumb for Evaluating Normed and Standardized Assessment Instruments in Psychology. Psychological Assessment, 6(4), 284-290.

Cohen, J. (1960). A Coefficient of Agreement for Nominal Scales. Educational and Psychological Measurement, 20(1), 37-46.

Crawford, K., Gordon, S., Nicholas, J., \& Prosser, M. (1994). Conceptions of Mathematics and How it is Learned: The Perspectives of Students Entering University. Learning and Instruction, 4(4), 331-345. https://doi.org/10.1016/0959-4752(94)90005-1

Dossey, J. A. (1992). The Nature of Mathematics: Its Role and its Influence. In D. A. Grouws (Ed.), Handbook of Research on Mathematics Teaching and Learning: A Project of the National Council of Teachers of Mathematics (pp. 39-48). New York: Macmillan Publishing Company.

Grouws, D. \& Cebulla, K. (2000). Improving Student Achievement in Mathematics. Geneva: International Academy of Education.

Haggarty, L. \& Pepin, B. (2002). An Investigation of Mathematics Textbooks and Their Use in English, French and German Classrooms: Who gets an opportunity to learn what? British Educational Research Journal, 28(4), 567-590. https://doi.org/10.1080/0141192022000005832

Halliday, M. (1985). An introduction to Functional Grammar. London: Edward Arnold. Eisenmann, B. (2007). From Intended Curriculum to Written Curriculum: Examining the "Voice" of a Mathematics Textbook. Journal for Research in Mathematics Education, 38(4), 344-369.

Halliday, M. \& Matthiessen, C. (2004). An Introduction to Functional Grammar. Third edition. London: Edward Arnold.

Halliday, M. (1978). Language as Social Semiotic: The Social Interpretation of Language and Meaning. London: Edward Arnold.

Halliday, M., (1973). Explorations in the Functions of Language, London: Edward Arnold.

Herbel-Eisenmann, B. \& Wagner, D. (2007). A Framework for the Uncovering the Way a Textbook May Position the Mathematics Learner. For the Learning of Mathematics, 27(2), 8-14. FLM Publishing Association, Edmonton, Alberta, Canada.

Herbel-Eisenmann, B. (2007). From Intended Curriculum to Written Curriculum: Examining the "Voice" of a Mathematics Textbook. Journal for Research in Mathematics Education, 38(4), 344-369. http://doi.org. 10.2307/30034878

Hiebert, J. Gallimore, R., Garnier, H., Givvin, K., Hollingsworth, H., Jacobs, J., Chui, A., Wearne, D., Smith, M., Kersting, N., Manaster, A., Tseng, E., Etterbeek, W., Manaster, C., 
Gonzales, P. \& Stigler, J. (2003). Teaching Mathematics in Seven Countries: Results from the TIMSS 1999 video study. DIaNe Publishing.t

Meaney, T., Trinick, T. \& Fairhall, U. (2012). Collaborating to Meet Language Challenges in Indigenous Mathematics Classrooms. London: Springer.

Morgan, C. \& Sfard, A. (2011). The Evolution of School Mathematics Discourse as Seen Through the Lens of GCSE Examinations. Poster Presented at the Seventh Congress of the European Society for Research in Mathematics Education.

Morgan, C. \& Tang, S. (2012). Studying Changes in School Mathematics Over Time the Lens of Examinations: The case of student positions. In T.Y. Tso (Ed.), Proceedings of the 36th Conference of the international group for the Psychology of Mathematics Education Vol. 3, pp. 241-248. Taipeim Taiwan: PME.

Morgan, C. (1996). The Language of Mathematics: Towards a Critical Analysis of Mathematical Text. For the Learning of Mathematics, 16(3), 2-10.

Morgan, C. (2001). Mathematics and Human Activity: Representation in Mathematical Writing. In C. Morgan \& K. Jones (Eds), Research in Mathematics Education Volume 3: Papers of the British Society for Research into Learning Mathematics (pp.169-182). London: British Society for Research into Learning Mathematics.

Morgan, C. (2004). Words, Definitions and Concepts in Discourses of Mathematics, Teaching and Learning. Language and Education, 19(2), 103-117.

Morgan, C. (2004). Writing Mathematically: The Discourse of Investigation. London: Falmer Press. Morgan, C. (2006). What does Social Semiotics have to Offer Mathematics Education Research? Educational Studies in Mathematics, 61(1) 219-245.

Moschkovich, J. (2010). Language and Mathematics Education: Multiple perspectives and directions for Research. Charlotte, NC: Information Age Publishing.

NCTM. (2000). Principles and Standards for School Mathematics. Reston, VA: NCTM.

O'Donnell, M., Zappavigna, M. \& Whitelaw, C. (2008). A Survey of Process Type Classification Over Difficult Cases. In J. Carys \& E. Ventola (Eds.). From Language to Multimodality: New Developments in the Study of Ideational Meaning (pp. 47-64). Continuum: London.

O'Keeffe, L. \& Donoghue, J. (2015). A Role for Language Analysis in Mathematics Textbook Analysis. International Journal of Science and Mathematics Education. 13(3), 605-630.

O'Keeffe, L. \& O'Donoghue, J. (2011). Mathematics Textbook Analysis: The Significance of Textbook Features to Student Learning. Paper presented at the 7th Congress of the European Society for Research in Mathematics Education (CERME 7). February 9th-13th. Rzeszów, Poland.

O'Keeffe, L. (2013). A Framework for Textbook Analysis. International Review of Contemporary Learning Research, 2(1), 1-13. http://dx.doi.org/10.12785/IRCLR/020101

Pape, S. \& Wang, C. (2003). Middle School Children's Strategic Behavior: Classification and Relation to Academic Achievement and Mathematical Problem Solving, Instructional Science, 31(6), 419-449. https://doi.org/10.1023/A:1025710707285

Petocs, P., Wood, L., Smith, G., Mather, G., Harding, A., Engelbrecht, J., et al., (2006). Undergraduate Student's Conceptions of Mathematics: An international study. International 
Journal of Science and Mathematics Education, (2007) 5, 439-459. https://doi.org/10.1007/ s10763-006-9059-2

Presmeg, N., Radford, L., Roth, W. \& Kadunz, G. (2016). Semiotics in Mathematics Education. Springer International Publishing. http://doi 10.1007/978-3-319-31370-2

Qaisi, T. (2014), Identifying THE Realization of Mathematical Connectivity Standard in 8th Grade Math Book in Jordan, and its Actualization in Classroom Practice. The Educational Journal, 28(112), 77-117.

Rababah,, E., \& Miqdadi, R. (2017). An Analysis of Jordan's Adherence to the NCTM Standards for First Grade Reformed Mathematics Textbooks, the Jordanian Journal of Educational Sciences, 13(2), 251-262.

Ramamneh, A., Abu Lum, K., Karameen, R. \& Hiasat, M. (2015). Analyze the Content of the Mathematics Books of the First to Fourth Grades of the Foundational Schooling Stage in Jordan, in Light of the Standards of the National Council for Teachers of Mathematics (NCTM 2000), Palestine University Journal for Research and Studies, 5(2), 1-32.

Schleppegrell, M. (2007). The Linguistic Challenges of Mathematics Teaching and Learning: A Research Review. Reading \& Writing Quarterly, 23(2), 139-159. http://doi. 10.1080/10573560601158461

Schoen, H., Cebulla, K., Finn, K. \& Fi, C. (2003). Teacher Variables that Relate to Student Achievement when Using a Standards-based Curriculum. Journal for Research in Mathematics Education, 34(3), 228-259."

Setati, M. (2002), Researching Mathematics Education and Language in Multilingual South Africa. The Mathematics Educator, 12(2), 6-20.

Sharafa, H. (2015). Analyzing Geometry in the Palestinian Mathematics Textbooks Using Linguistic Approach (Unpublished MA Thesis), Birzeit University.

Shilling, L. (2010), An Exploration of Pre-Service Elementary Teachers Mathematical beliefs, Ph.D. dissertations of Education, University of Pittsburgh.

Shin, H. (2019). A Semiotic Analysis of Linguistic and Conceptual Development in Mathematics for English Language Learners. Ph.D. dissertations of Education, University of Massachusetts Amherst. Shwaikh, J. \& Morgan, C. (2013). Analyzing the Palestinian school mathematics textbooks: A muktimodal (multisemiotic) perspective. Proceedings of the British Society for Research into Learning Mathematics, 33(2), 70-75.

Shwaikh, J. (2012). Mathematics, Language and Communication. A research paper presented at the conference "The Arabic Language in Palestinian Universities between Reality and Tom". Birzeit University, Palestine.

Sovič, A. \& Hus, V. (2016). Semiotic Analysis of the Textbooks for Young Learners, Creative Education. 7(1), 639-645. https://doi. 10.4236/ce.2016.74066

Tang, S., Morgan, C. \& Sfard, A. (2012). Investigating the Evolution of School Mathematics through the Lens of Examinations: Developing an Analytical Framework. Paper presented at the 12th International Congress on Mathematical Education, Topic Study Group 28 on Language and Mathematics, Seoul, Korea. 
Torbeyns, J., Schneider, M., Xin, Z. \& Siegler, R. (2015). Bridging the Gap: Fraction Understanding is Central to Mathematics Achievement in Students from Three Different Continents. Learning and Instruction, 37, 5-13. https://doi.org/10.1016/j.learninstruc.2014.03.002

Troelstra, A., \& Van Dalen, D. (2014). Constructivism in Mathematics (Vol. 2). Elsevier.

\title{
9 klasės matematikos vadovèlio semiotinès charakteristikos
}

\author{
Mohammad Ahmad Alkhateeb
}

Hašimitų universitetas, Zarka, Jordanija,mkm7879@yahoo.com

\section{Santrauka}

Matematikos kalba labai svarbi matematikos pamokose ir vadovèliuose. Vis dèlto kalba labai sudètinga ir kalbos analizès metodai yra nepakankami, kad būtų galima veiksmingai ịvertinti matematikos kalbą bei atskleisti jos bruožus matematikos vadovèliuose. Atliekant ši tyrimą buvo panaudotas socialinis semiotinis metodas, kuriuo siekta išanalizuoti 9 klasès matematikos vadovèli Jordanijos mokiniams. Ši metodologija analizuoja tris su tekstais susijusius aspektus: intelektinę funkciją, tarpasmeninę funkciją ir tekstinę funkciją. Analizuojant intelektinių funkcijų kategorijas buvo naudojamos O’Keffee ir O’Donoghue (2011) išskirtos kategorijos, o tarpasmeninei funkcijos analizei buvo pasirinkti įvardžiai, kurie buvo nagrinėjami tekstuose, t. y. Halliday (1985), Morgan (2006) darbuose. Tekstinei funkcijai analizuoti pasitelktas Shwaikh ir Morgan (2013) darbas. Kiekybinis tyrimo metodas buvo naudojamas apskaičiuoti intelektinès, tarpasmeninès ir tekstinès funkcijos kiekvienos iš t kategorijų dažnius.

Rezultatai parodé, kad matematika yra abstrakti, formali, simbolinè ir savimi pagrịsta ir kad matematika egzistuoja kaip nepriklausoma sritis su visais matematiniais bruožais, išlaikanti oficialų ir tolimą ryši „tarp knygos ir mokinio“. Matematikos vadovèlio turinys tarsi linkęs parodyti mokiniams, kad jie tik užsakymų vykdytojai, nekreipiama dèmesio į mokinių pažangą, t. y. perẻjimą nuo ankstesnių žinių iki naujų žinių igijimo. Todèl šiame tyrime raginama parengti tokius matematikos vadovèlius, kurie atskleistų kitokị matematikos ịvaizdị, kad mokiniai galètų efektyviai įsitraukti į mokymosi procesą, kad būtų suteikiama galimybè mąstyti, o ne vien vykdyti mechaniškas užduotis.

Esminiai žodžiai: intelektinéfunkcija, tarpasmeniné funkcija, tekstiné funkcija, matematikos vadovèlių analizé, sisteminè funkciné kalbotyra. 